\title{
Fertility assessment of mountainous soils of District Skardu, Gilgit-Baltistan, Pakistan
}

\author{
Zakir Hussain ${ }^{1}$, Majid Mahmood Tahir ${ }^{2 *}$, Nasir Rahim², Abdul \\ Khaliq $^{2}$, Zakir Hussain Facho ${ }^{1}$, Hassan Shafqat ${ }^{1}$, Ishtiaq Hussain ${ }^{1}$ and \\ Aqila Shaheen ${ }^{2}$ \\ 1. Soil Research Laboratory, Agriculture Department, Skardu, Gilgit-Baltistan-Pakistan \\ 2. Department of Soil and Environmental Sciences, Faculty of Agriculture, University of the Poonch, \\ Rawalakot, Azad Jammu and Kashmir-Pakistan \\ *Corresponding author's email: majidmahmood@upr.edu.pk \\ Citation \\ Zakir Hussain, Majid Mahmood Tahir, Nasir Rahim, Abdul Khaliq, Zakir Hussain Facho, Hassan Shafqat, \\ Ishtiaq Hussain and Aqila Shaheen. Fertility assessment of mountainous soils of District Skardu, Gilgit- \\ Baltistan, Pakistan. Pure and Applied Biology. Vol. 8, Issue 3, pp2095-2103. \\ http://dx.doi.org/10.19045/bspab.2019.80154
}

\begin{tabular}{llll}
\hline \hline Received: 02/05/2019 & Revised: 15/07/2019 & Accepted: 25/07/2019 & Online First: 03/08/2019 \\
\hline \hline
\end{tabular}

\section{Abstract}

Land degradation is a serious problem in mountainous (Northern) areas of Pakistan. Improvement of soil fertility and productivity begins with the knowledge of existing fertility status. However there is little information regarding the current fertility status of soils of northern areas of Pakistan. Therefore, present study was conducted in three union councils of District Skardu to investigate soil fertility status. A total of 30 soil samples $(0-15 \mathrm{~cm}$ depth) from 10 sites in each of three union councils of Skardu were collected. Soil samples were analyzed for $\mathrm{pH}, \mathrm{EC}$, organic matter, $\mathrm{NO}_{3}-\mathrm{N}, \mathrm{AB}-\mathrm{DTPA}$ extractable $\mathrm{P}$, and $\mathrm{K}$. Results revealed that the soils in the three union councils were slightly acidic to slightly alkaline with $\mathrm{pH}$ ranging from 6.29 to 7.80 with no salinity problem. The EC of the soils ranged between 0.52 to 0.62 $\mathrm{dS} \mathrm{m} \mathrm{m}^{-1}$. The soils on an average contain adequate amount of soil organic matter ranging between 1.40 to $1.67 \%$. Soil analysis showed that $70 \%$ of the soil samples were deficient in $\mathrm{NO}_{3}-\mathrm{N}$, $80 \%$ soil samples were deficient in extractable $\mathrm{P}$ while $100 \%$ soil samples were deficient in K. On the basis of the results obtained it is clearly evident that serious efforts should be made for soil and plant nutrient management in the area.

Keywords: Deficiency; Fertility; Gilgit; Mountains; Nutrients; Skardu

\section{Introduction}

Mountains occupy $61 \%$ of the geographical area of Pakistan and are home to 40 million people of the country. The livelihood and food security of mountainous people depends on local soil resources [1]. Depletion of soil resources across mountains resulted in considerable loss of valuable ecosystem services, principally in terms of soil fertility, due to their topography, altitude and cropping practices. The loss of soil fertility has reduced food productivity, thereby increasing food insecurity and vulnerability of people [2]. Additionally, climate change has brought new challenges for people living in mountains in terms of water availability due to rising temperature. Globally, soils in mountains are becoming important due to environmental services such as carbon sequestration and watershed management [3]. Therefore, sustainable use 
of these soils is much more required now than before.

Soil properties vary spatially and temporally from a field to a larger region scale, and are influenced by both intrinsic and extrinsic factors [4]. The high altitude of Northern areas of Pakistan and climatic conditions are mainly responsible for different texture, mineralogy and soil fertility. The inherent soil fertility and soil loss through erosion are deeply influenced by altitude and topography [5]. The variations in amount of precipitation, snowfall and temperature affects accumulation and decomposition of soil organic matter (SOM) [6]. These variations in turn affect fertility status of the soils in the region. Many soil fertility characteristics i.e. $\mathrm{pH}$, cation exchange capacity (CEC), SOM, available phosphorus, extractable potassium and nitrogen have been reported to show significant variations across mountainous soils [6]. Therefore, precise soil fertility assessments are important for sustainable productivity, particularly in soils of low inherent fertility or prone to soil degradation.

Soil fertility assessment includes measurement of available essential plant nutrients and the ability of the soils in terms of maintaining a continuous supply of these nutrients to crops. Globally, different methods are used for soil fertility assessment, however, soil testing is commonly used [7]. During soil testing, current fertility status of the soil is determined and on the basis of this information recommendations for nutrient management are suggested to maintain adequate soil fertility for longer time [8]. Nutrient management and crop production vary from soil to soil and depends on their physico-chemical behavior $[9,10]$. Therefore, soil resources should be managed carefully for sustainable crop production. Keeping in view the importance of soil fertility assessment, present study was designed to provide information on the current fertility status of agricultural soils in three union councils of District Skardu, Gilgit-Baltistan, Pakistan.

\section{Materials and methods}

\section{Study area}

Soil samples were collected from District Skardu, located along the Kohistan-Ladakh terrane $\left(35^{\circ} 17^{\prime} 25^{\prime \prime} \mathrm{N} 75^{\circ} 38^{\prime} 40^{\prime \prime} \mathrm{E}\right)$, at an elevation of $2300 \mathrm{~m}$ above sea level in the Northern areas of Pakistan at the confluence of the Indus and Shigar Rivers. The study area has a climate described as cold semi-arid climate with mild summers and relatively cold winters. Maximum air temperature during summer is $27{ }^{\circ} \mathrm{C}$ in April and minimum of $8^{\circ} \mathrm{C}$ in October while lowest winter temperature of $-10{ }^{\circ} \mathrm{C}$ is observed during January and February with mean annual precipitation of around 172 $\mathrm{mm}$, mostly downpours between January and May. The soils of the area are mostly silty clay loam and wheat, barley, potato, maize, peas, carrot and tomato are common crops. Cultivation is mostly done with chisel and wooden plough.

\section{Soil sampling and processing}

A total of 30 composite soil samples were collected from the three union councils of District Skardu i.e. Skardu Khas

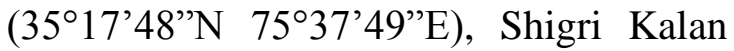
$\left(35^{\circ} 16^{\prime} 44^{\prime \prime N} \quad 75^{\circ} 36^{\prime} 48^{\prime \prime} \mathrm{E}\right)$ and Shigri Khurd (35'17'45'N 75'32'46”E). Soil samples were collected randomly (random soil sampling) from small sized crop fields. At each union council, ten sampling points were selected and samples were collected from 0 to $15 \mathrm{~cm}$ soil depth (plough layer) with the help of soil auger. At each location (sampling point), five samples were collected in close vicinity and composited. After sampling, the soil samples were stored in polyethylene bags and transferred to the Soil Testing Laboratory, Department of Agriculture Skardu, Baltistan. In the laboratory, all visible plant residues were removed from soil samples, air dried (room temperature) and sieved (2-mm).

\section{Soil analysis}

Electrical conductivity (EC) and $\mathrm{pH}$ of the soil samples were measured by the method as described by Tandon [11]. Wet digestion 
method of Walkley and Black [12] was used to determine soil organic carbon (SOC) and soil organic matter (SOM) was calculated by multiplying SOC with Van Bemmelen factor (1.724). Nitrate nitrogen $\left(\mathrm{NO}_{3}-\mathrm{N}\right)$, phosphorus and potassium were determined by AB-DTPA extractable method [13]. After soil analysis, soils were categorized as deficient, marginal, adequate and high in accordance with generalized soil nutrients ranges as described by Rayan et al. [14] (Table 1).

\section{Statistical analysis}

Data obtained from the study was analyzed using Statistix 8.1 statistical software. Analysis of variance (ANOVA) was used to identify statistically significant differences in $\mathrm{pH}, \mathrm{EC}, \mathrm{SOC}, \mathrm{NO} 3-\mathrm{N}, \mathrm{P}$ and $\mathrm{K}$ values among sampling locations and between union councils. Significant differences between locations and union councils were identified by Least Significant Different test $(\mathrm{P}<0.05)$.

\section{Results}

\section{EC and pH}

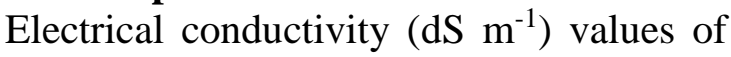
the soils of Skardu khas, Shigri khurd and Shigri kalan union councils ranged from $0.12-0.95,0.06-0.88$ and $0.25-0.75$ with mean values of $0.52 \pm 0.31,0.44 \pm 0.31$ and $0.68 \pm 0.74$, respectively (Table $2,3 \& 4$ ). The EC of the soils showed that soil samples were non-saline. The EC of three union councils were in order of Shigri kalan> Skardu khas> Shigri khurd (Figure 1a). The $\mathrm{pH}$ values of the soils of Skardu khas, Shigri khurd and Shigri kalan union councils ranged from 6.29-7.73, 6.83-7.80 and 6.40-7.73 with mean values of $7.28 \pm 0.12, \quad 7.24 \pm 0.09$ and $7.31 \pm 0.11$, respectively (Table $2,3 \& 4$ ). The $\mathrm{pH}$ values in the three union councils were in order Shigri kalan $>$ Skardu khas $>$ Shigri khurd (Figure 1b).

\section{Organic matter}

Soil organic matter contents of the soils of Skardu khas, Shigri khurd and Shigri kalan union councils ranged from $0.54-2.88 \%$, $0.08-3.02 \%$ and $0.58-3.57 \%$ with mean values of $1.67 \pm 0.17, \quad 1.40 \pm 0.11$ and
$1.48 \pm 0.18$, percent respectively (Table 2,3 \& 4). Distribution of soil samples with respect to SOM content indicates that about $20 \%$ samples had very low organic matter, $23 \%$ were low and while $57 \%$ had medium organic matter. Average SOM content in the three union councils were in order Skardu khas > Shigri kalan > Shigri khurd (Figure 1c).

Nitrogen, phosphorus and potassium

$\mathrm{NO}_{3}-\mathrm{N}$ contents of the soils of Skardu khas, Shigri khurd and Shigri kalan union councils ranged from 1.45-16.23, 0.7314.37 and $0.40-14.06 \mathrm{mg} \mathrm{kg}^{-1}$ with mean values of $7.08 \pm 0.46,7.03 \pm 0.36$ and $6.89 \pm 1.04 \mathrm{mg} \mathrm{kg}^{-1}$, respectively (Table 2,3 \& 4). Distribution of soil samples with respect to $\mathrm{NO}_{3}-\mathrm{N}$ content indicates that about $70 \%$ soil samples were deficient while $30 \%$ soil samples had marginal $\mathrm{NO}_{3}-$ $\mathrm{N}$ (Table 1). Average $\mathrm{NO}_{3}-\mathrm{N}$ content in the three union councils were in order Skardu khas $>$ Shigri khurd $>$ Shigri kalan (Figure 1d). AB-DTPA extractable phosphorus of the soils of Skardu khas, Shigri khurd and Shigri kalan union councils ranged from $0.16-11.81,1.27-12.12$ and $0.47-13.77 \mathrm{mg}$ $\mathrm{kg}^{-1}$ with mean values of $3.47 \pm 0.31$, $5.63 \pm 0.46$ and $0.92 \pm 44 \mathrm{mg} \mathrm{kg}^{-1}$, respectively (Table $2,3 \& 4$ ). Distribution of soil samples with respect to $\mathrm{P}$ content indicates that about $43 \%$ of soil samples were deficient, $37 \%$ had marginal, $10 \%$ had adequate while $10 \%$ had high $\mathrm{P}$ (Table 1). Average $\mathrm{P}$ concentration in the three union councils were in order Shigri khurd > Skardu khas $>$ Shigri kalan (Figure 1e). ABDTPA extractable potassium of the soils of Skardu khas, Shigri khurd and Shigri kalan union councils ranged from 8.14-43.90, 15.16-110.91 and $11.80-36.62 \mathrm{mg} \mathrm{kg}^{-1}$ with mean values of $25.94 \pm 0.31,51.17 \pm 0.46$ and $22.36 \pm 44 \mathrm{mg} \mathrm{kg}^{-1}$, respectively (Table 2, 3 $\& 4)$. Distribution of soil samples with respect to $\mathrm{K}$ content indicates that about 87 $\%$ samples had low $\mathrm{K}$ while $13 \%$ samples had marginal K (Table 1). Average K concentration in the three union councils were in order Shigri khurd > Shigri kalan > Skardu khas (Figure 1f). 
Table 1. Generalized soil nutrient ranges for interpreting soil nutrient status*

\begin{tabular}{|c|c|c|c|c|}
\hline \multirow{2}{*}{ Nutrients } & Deficient & Marginal & Adequate & High \\
\cline { 2 - 5 } & \multicolumn{3}{|c|}{ AB-DTPA - extractable $\left(\mathrm{mg} \mathrm{kg}^{-1}\right)$} \\
\hline $\mathbf{N O}_{3}-\mathbf{N}$ & $<10$ & $11-20$ & $21-30$ & $>20$ \\
\hline $\mathbf{P}$ & $<3$ & $4-7$ & $8-11$ & $>11$ \\
\hline $\mathbf{K}$ & $<60$ & $60-120$ & $121-180$ & $>180$ \\
\hline
\end{tabular}

*Ryan et al. (2001)

Table 2. Soil fertility status of some selected sites in Skardu Khas area of District Skardu, Gilgit, Baltistan, Northern areas, Pakistan $\left({ }^{\dagger}\right)$

\begin{tabular}{|c|c|c|c|c|c|c|}
\hline Locations & $\begin{array}{c}\mathbf{E C} \\
\left(\mathbf{d S ~ m} \mathbf{~ m}^{-\mathbf{1}}\right)\end{array}$ & $\mathbf{p H}$ & $\begin{array}{c}\mathbf{O M} \\
(\mathbf{\%})\end{array}$ & $\begin{array}{c}\mathbf{N O}_{\mathbf{3}} \mathbf{- N} \\
\left(\mathbf{m g ~ k g}^{-1}\right)\end{array}$ & $\begin{array}{c}\mathbf{P} \\
\left(\mathbf{m g ~ k g}^{-1}\right)\end{array}$ & $\begin{array}{c}\mathbf{K} \\
\left(\mathbf{m g ~ k g}^{-1}\right)\end{array}$ \\
\hline Muarfee colony & $0.21 \mathrm{e}$ & $7.63 \mathrm{ab}$ & $0.54 \mathrm{f}$ & $1.45 \mathrm{~h}$ & $0.16 \mathrm{~g}$ & $8.14 \mathrm{f}$ \\
\hline Sukamaidan & $0.76 \mathrm{~b}$ & $6.29 \mathrm{f}$ & $2.82 \mathrm{a}$ & $11.77 \mathrm{~b}$ & $11.81 \mathrm{a}$ & $36.74 \mathrm{~b}$ \\
\hline Hassan colony & $0.44 \mathrm{~d}$ & $7.17 \mathrm{~d}$ & $2.35 \mathrm{~b}$ & $10.73 \mathrm{c}$ & $4.47 \mathrm{~b}$ & $32.04 \mathrm{c}$ \\
\hline Abbas town & $0.87 \mathrm{a}$ & $6.83 \mathrm{e}$ & $1.17 \mathrm{e}$ & $5.15 \mathrm{f}$ & $4.33 \mathrm{bc}$ & $25.97 \mathrm{~d}$ \\
\hline Patwal & $0.12 \mathrm{f}$ & $7.23 \mathrm{~cd}$ & $1.91 \mathrm{bc}$ & $9.53 \mathrm{~d}$ & $1.79 \mathrm{ef}$ & $30.94 \mathrm{c}$ \\
\hline Krasmathang & $0.71 \mathrm{~b}$ & $7.70 \mathrm{a}$ & $2.88 \mathrm{a}$ & $16.23 \mathrm{a}$ & $3.75 \mathrm{~cd}$ & $43.90 \mathrm{a}$ \\
\hline Khargrong & $0.61 \mathrm{c}$ & $7.43 \mathrm{bc}$ & $1.76 \mathrm{~cd}$ & $6.89 \mathrm{e}$ & $3.43 \mathrm{~d}$ & $26.28 \mathrm{~d}$ \\
\hline Nagolispang & $0.14 \mathrm{ef}$ & $7.73 \mathrm{a}$ & $1.36 \mathrm{de}$ & $3.31 \mathrm{~g}$ & $1.54 \mathrm{ef}$ & $27.34 \mathrm{~d}$ \\
\hline Kuro & $0.95 \mathrm{a}$ & $7.23 \mathrm{~cd}$ & $1.50 \mathrm{cde}$ & $2.25 \mathrm{~h}$ & $1.34 \mathrm{f}$ & $16.66 \mathrm{e}$ \\
\hline Hussain Abad & $0.37 \mathrm{~d}$ & $7.50 \mathrm{ab}$ & $0.44 \mathrm{f}$ & $3.49 \mathrm{~g}$ & $2.09 \mathrm{e}$ & $11.39 \mathrm{f}$ \\
\hline Mean & 0.52 & 7.28 & 1.67 & 7.08 & 3.47 & 25.94 \\
\hline LSD & 0.08 & 0.26 & 0.46 & 0.90 & 0.70 & 3.47 \\
\hline
\end{tabular}

${ }^{\dagger}$ Means with different letters in column are significantly different at $P<0.05$ using LSD

Table 3. Soil fertility status of some selected sites in Shigri Khurd area of District Skardu, Gilgit, Baltistan, Northern areas, Pakistan $\left({ }^{\dagger}\right)$

\begin{tabular}{|c|c|c|c|c|c|c|}
\hline Location & $\begin{array}{c}E C \\
\left(d^{-1} ~ m^{-1}\right)\end{array}$ & pH & $\begin{array}{l}\text { OM } \\
(\%)\end{array}$ & $\begin{array}{c}\mathrm{NO}_{3}-\mathrm{N} \\
\left(\mathrm{mg} \mathrm{kg}^{-1}\right)\end{array}$ & $\begin{array}{c}\mathbf{P} \\
\left(\mathbf{m g ~ k g}^{-1}\right)\end{array}$ & $\underset{\left(\mathrm{mg} \mathrm{kg}^{-1}\right)}{\mathbf{K}}$ \\
\hline Youltar & $0.11 \mathrm{~g}$ & $7.27 \mathrm{bcd}$ & $2.79 \mathrm{ab}$ & $12.31 \mathrm{~b}$ & $10.09 \mathrm{~b}$ & $95.96 \mathrm{~b}$ \\
\hline Sadpara & $0.24 \mathrm{e}$ & $7.80 \mathrm{a}$ & $1.13 \mathrm{~d}$ & $6.91 \mathrm{c}$ & $5.47 \mathrm{~d}$ & $28.63 d$ \\
\hline Katpana & $0.78 b$ & 7.10de & $2.13 \mathrm{c}$ & $11.98 \mathrm{~b}$ & $6.84 \mathrm{c}$ & $71.45 \mathrm{c}$ \\
\hline Ranga & $0.88 \mathrm{a}$ & $7.43 b$ & $3.02 \mathrm{a}$ & $14.37 \mathrm{a}$ & $12.12 \mathrm{a}$ & 110.91a \\
\hline Sundus & $0.82 \mathrm{~b}$ & $7.30 \mathrm{bcd}$ & $0.44 \mathrm{f}$ & $2.63 \mathrm{e}$ & $2.38 \mathrm{ef}$ & $23.78 \mathrm{de}$ \\
\hline Ragayul & $0.28 \mathrm{e}$ & $6.83 \mathrm{f}$ & $0.76 \mathrm{e}$ & $2.09 \mathrm{e}$ & $2.34 \mathrm{ef}$ & $23.44 \mathrm{de}$ \\
\hline Rsasna & $0.42 \mathrm{~d}$ & $7.33 \mathrm{bc}$ & $2.67 \mathrm{~b}$ & $12.79 b$ & $10.48 b$ & $99.62 \mathrm{ab}$ \\
\hline Newranga & $0.66 \mathrm{c}$ & $6.97 \mathrm{ef}$ & $0.77 \mathrm{e}$ & $5.43 d$ & $3.26 \mathrm{e}$ & $25.47 \mathrm{de}$ \\
\hline Kushmara & $0.06 \mathrm{~g}$ & $7.13 \mathrm{cde}$ & $0.08 \mathrm{~g}$ & $0.73 \mathrm{f}$ & $1.27 \mathrm{~g}$ & $15.16 \mathrm{e}$ \\
\hline Astana & $0.17 \mathrm{f}$ & $7.20 \mathrm{~cd}$ & $0.21 \mathrm{fg}$ & $1.01 \mathrm{f}$ & $2.08 \mathrm{fg}$ & $17.25 \mathrm{e}$ \\
\hline Mean & 0.44 & 7.24 & 1.40 & 7.03 & 5.63 & 51.17 \\
\hline LSD & 0.05 & 0.21 & 0.27 & 1.04 & 1.06 & 11.35 \\
\hline
\end{tabular}

Means with different letters in column are significantly different at $P<0.05$ using LSD 
Table 4. Soil fertility status of some selected sites in Shigri Kalan area of District Skardu, Gilgit, Baltistan, Northern areas, Pakistan $\left({ }^{\dagger}\right)$

\begin{tabular}{|c|c|c|c|c|c|c|}
\hline Location & $\begin{array}{c}\mathrm{EC} \\
\left(\mathrm{dS} \mathrm{m}^{-1}\right)\end{array}$ & pH & $\begin{array}{l}\text { OM } \\
(\%)\end{array}$ & $\begin{array}{c}\mathrm{NO}_{3}-\mathrm{N} \\
\left(\mathrm{mg} \mathrm{kg}^{-1}\right)\end{array}$ & $\begin{array}{c}\mathbf{P} \\
\left(\mathrm{mg} \mathrm{kg}^{-1}\right)\end{array}$ & $\begin{array}{c}\mathrm{K} \\
\left(\mathrm{mg} \mathrm{kg}^{-1}\right)\end{array}$ \\
\hline Upper chunda & $0.71 \mathrm{~b}$ & $7.73 a$ & $1.93 \mathrm{c}$ & $0.40 \mathrm{e}$ & $9.93 b$ & $21.17 \mathrm{~cd}$ \\
\hline Lower chunda & $0.66 c$ & $6.83 \mathrm{~d}$ & $2.67 \mathrm{~b}$ & $2.15 \mathrm{de}$ & $13.77 \mathrm{a}$ & $33.01 \mathrm{ab}$ \\
\hline Gamba & $0.26 \mathrm{~g}$ & $7.44 \mathrm{~b}$ & $0.66 \mathrm{~g}$ & $7.25 b$ & $2.54 \mathrm{f}$ & $36.62 \mathrm{a}$ \\
\hline Mangar & $0.25 \mathrm{~g}$ & $7.51 \mathrm{ab}$ & $1.48 \mathrm{~d}$ & $14.06 \mathrm{a}$ & $3.67 \mathrm{e}$ & $13.12 \mathrm{e}$ \\
\hline Shigri bala & $0.36 \mathrm{f}$ & $7.40 \mathrm{bc}$ & $0.58 \mathrm{~g}$ & $6.29 b c$ & $0.47 \mathrm{i}$ & $11.80 \mathrm{e}$ \\
\hline Behnid & $0.37 f$ & $7.73 a$ & $3.57 \mathrm{a}$ & $4.51 \mathrm{~cd}$ & 0.80hi & $15.48 \mathrm{de}$ \\
\hline Arif abad & $0.75 a$ & $7.17 \mathrm{c}$ & $0.87 \mathrm{fg}$ & $12.66 \mathrm{a}$ & $2.26 \mathrm{fg}$ & $22.01 \mathrm{~cd}$ \\
\hline Thayur & $0.46 \mathrm{e}$ & $7.53 \mathrm{ab}$ & $0.61 \mathrm{~g}$ & $8.83 \mathrm{~b}$ & $1.49 \mathrm{gh}$ & $25.13 c$ \\
\hline Hoto pakora & $0.54 \mathrm{~d}$ & $7.33 b c$ & $1.07 \mathrm{ef}$ & $4.20 \mathrm{~cd}$ & $4.94 \mathrm{~d}$ & $27.13 b c$ \\
\hline Tandal & $0.45 \mathrm{e}$ & $6.40 \mathrm{e}$ & $1.38 \mathrm{de}$ & $8.55 \mathrm{~b}$ & $6.88 \mathrm{c}$ & $18.13 \mathrm{de}$ \\
\hline Mean & 0.68 & 7.31 & 1.48 & 6.89 & 4.68 & 22.36 \\
\hline LSD & 0.03 & 0.26 & 0.38 & 2.58 & 0.92 & 6.69 \\
\hline
\end{tabular}

Means with different letters in column are significantly different at $P<0.05$ using LSD

\section{Discussion}

\section{EC and pH}

Determination of soil $\mathrm{EC}$ and $\mathrm{pH}$ is important to understand soil chemical behavior and nutrient availability [15]. Dahnke \& Whitney [16] categorized EC $\left(\mathrm{dS} \mathrm{m} \mathrm{m}^{-1}\right)$ values as follows: $0.0-1.4=$ nonsaline, $1.5-2.8=$ slightly saline and 2.9-5.7 as moderately saline. In view of this, the soils in the three union council of District Skardu were mostly non-saline to slightly saline. Low EC in majority of the soil samples in the three union councils of District Skardu indicates low electrolyte concentration which is a matter of concern for maintaining adequate level of bases on sustainable basis [17]. The $\mathrm{pH}$ of most of the soils in the study areas were within the satisfactory range for crop production which is 5.5-7.0, as reported by Ashri [18]. Landon [19] categorized $\mathrm{pH}$ values as follows: $>8.5=$ very high, $7.0-8.5=$ high, $5.5-7.0=$ medium and $<5.5=$ low. In view of this, all soils in the study had medium to high $\mathrm{pH}$. The slightly alkaline nature of the soils might be due to the alkaline nature of the parent material, low-rainfall and high level of evapotranspiration [17]. The variations in soil $\mathrm{pH}$ and $\mathrm{EC}$ values among soil samples could be attributed to the variability in drainage pattern, calcium carbonate equivalent, soil organic matter, cropping sequence, fertilizer use and in leaching of bases [20]. Similar values for soil $\mathrm{pH}$ and $\mathrm{EC}$ were also reported by Babar et al. [21] and Jabeen et al. [20] who analyzed soils from the Northern areas of Pakistan including Gilgit and Skardu.

\section{Organic matter}

Pakistani soils are low in organic matter $(<1.0 \%)$ inherently [22]. Baize [23] categorized organic carbon contents of < $0.60 \%$ as very low, $0.60-1.25 \%$ as low and $(1.26-2.50 \%)$ as medium. On the basis of these categories and on an average of soil samples, soils in this study contain low to medium organic carbon content. Our results suggested that medium level of SOM in these mountainous soils as compared to other agricultural soils, will be helpful in improving soil physical and chemical properties, soil aggregation and reducing nutrient losses.

Our results are generally similar to the findings of earlier researchers who also observed low to medium SOM in soils of District Skardu and Gilgit [20, 21, 24]. The low SOM level in some soils might be due to altitudinal variability and topography influencing organic matter decomposition and density of natural vegetation. Variations in precipitation, snowfall, and temperature affects SOM decomposition which in turn affect its accumulation in soil [25]. 


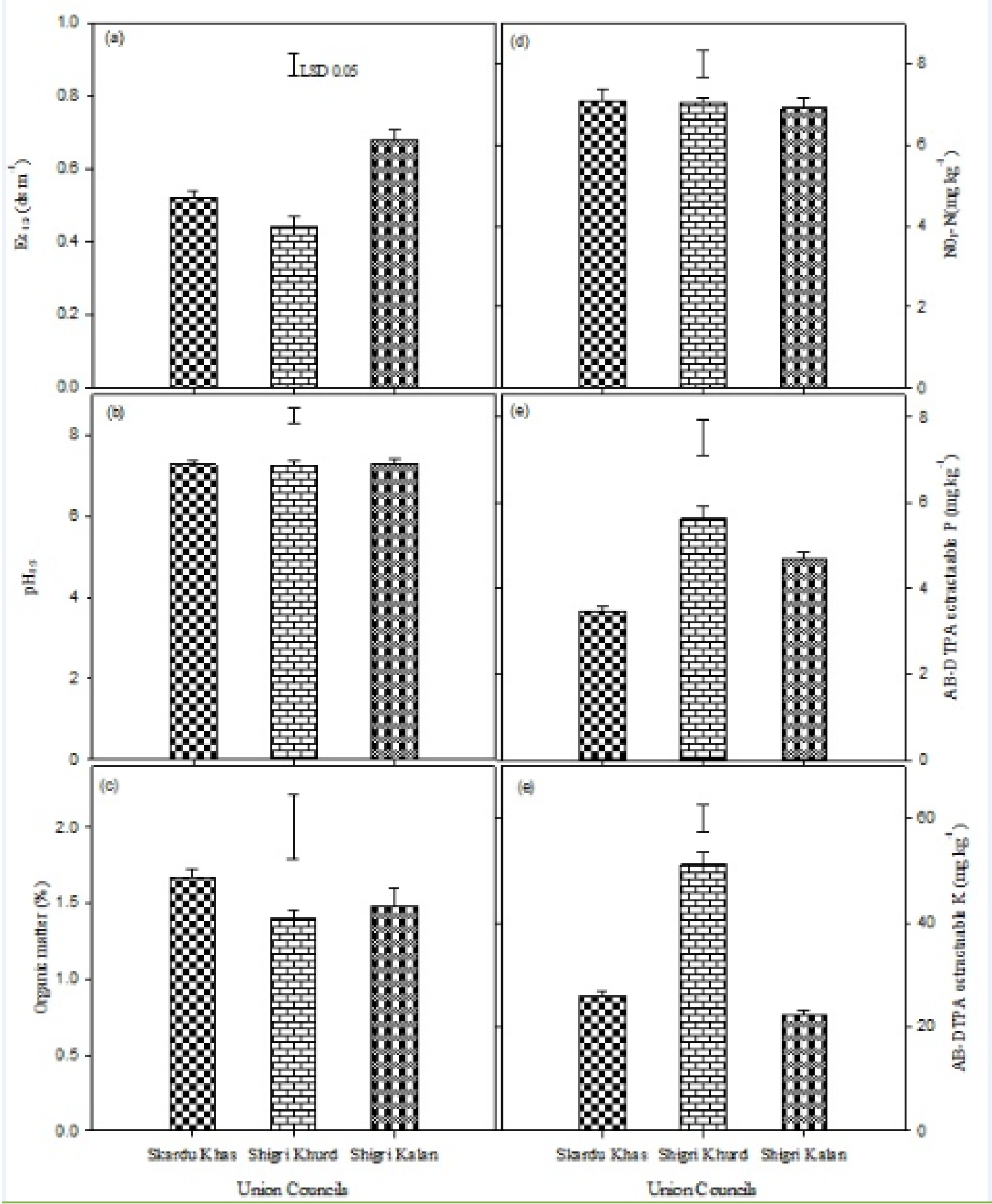

Figure 1. Variability in: a) Ec); b) $\mathrm{pH}$; c) organic matter; d) $\mathrm{NO}_{3}-\mathrm{N}$; e) AB-DTPA extractable phosphorus and f) AB-DTPA extractable potassium in soil samples $(n=10)$ collected from Skardu Khas, Shigri Khurd and Shigri Kalan, Skardu, Gilgit-Baltistan, Pakistan. Error bars represent standard deviation. Vertical bars in each graph indicate the least significant difference between union councils $(P<0.05)$

Additionally, low SOM content of mountainous soils are also due to the removal of surface soil by water erosion, nutrient mining with centuries old cropping, non-recycling of crop residues, and inadequate fertilizer use. It is also 
reported that soil erosion is mainly responsible for soil degradation and productivity of soils in mountainous areas [26]. Since, SOM is the fundamental source of plant nutrients and it improves soil physical, chemical and biological properties (soil structure, water infiltration and retention, feeds soil micro-flora and fauna, and the retention and cycling of applied fertilizer).

\section{Nitrogen, phosphorus and potassium}

The results of this study revealed that soils of the District Skardu were deficient in $\mathrm{NO}_{3}-\mathrm{N}$, extractable $\mathrm{P}$ and $\mathrm{K}$. The deficiency of $\mathrm{NO}_{3}-\mathrm{N}$ and variations in $\mathrm{NO}_{3}-\mathrm{N}$ content among soils could be linked with soil management, application of organicinorganic fertilizers to previous crop, temperature, rainfall and altitude [24]. The $\mathrm{N}$ content of the soils are mainly associated with the presence of organic matter. In the present study it was revealed that soil contains medium to low organic matter which might be responsible for low $\mathrm{N}$ in soils. Our results are in agreement with the findings of Sharma et al. [27] who reported that there is a definite relation of organic matter with $\mathrm{N}$ availability because organic matter adds sizeable amounts of $\mathrm{N}$ in mineral soil $\mathrm{N}$ pool through mineralization. Pakistani soils are predominantly derived from alluvium and loess material, alkaline in $\mathrm{pH}$, calcareous and low in organic matter and are low in many essential plant nutrients especially $\mathrm{P}$. It is commonly believed that $\mathrm{P}$ in organic fraction is less sensitive to AB-DTPA extraction. Keeping in view of the SOM and $\mathrm{pH}$ values, it is possible that organic $\mathrm{P}$ fraction of the soils was not fully extracted by AB-DTPA solution. Low $\mathrm{P}$ fertilizer input, in addition to formation of calcium phosphates as a result of calcareousness, limit extractable $\mathrm{P}$ in the soils. Another sink of phosphates identified in calcareous soils of arid region soils is its precipitation as secondary minerals of $\mathrm{Ca}-\mathrm{P}$ and $\mathrm{Mg}-\mathrm{P}$ [7, 28].

The soils sampled in present study were mostly deficient in extractable K. Most of the Pakistani soils usually contain adequate levels of K [29]. However, the findings of present study of extractable $\mathrm{K}$ were in line with those reported by Babar et al. [21] (2004) and Jabeen et al. [20] in the soils of the Northern areas of Pakistan. Differences in $\mathrm{NO}_{3}-\mathrm{N}$, extractable $\mathrm{P}$ and $\mathrm{K}$ among soil samples of one union council were mainly due to variations in altitude and organic matter contents of the soils. Additionally, drainage and slope pattern, cropping sequence and landscape position also influence macro-nutrient availability. Whiteman [30] reported that soils of the northern areas, derived from Regosols had little structure, free drainage and were low in organic matter. He also reported that intensive agricultural activities without integrated nutrient management will cause deficiency of major nutrients. The findings of our study show that most of the soils are now deficient in major nutrients. This situation demands integrated nutrient management system of farming so that farmer can produce on sustainable basis.

\section{Conclusion}

The results of the study showed that soils in the three union councils of District Skardu were found slightly acidic to slightly alkaline in nature with no salinity problem. Organic matter ranged from low to medium while deficiency of $\mathrm{NO}_{3}-\mathrm{N}$, extractable $\mathrm{P}$ and $\mathrm{K}$ was observed in soil samples analyzed. In general, the soils need suitable amendments to overcome nutrient deficiencies. Keeping in view the nature of the area, it is concluded that a comprehensive soil survey of the area should be done to develop nutrient management practices for sustainable crop production.

\section{Authors' contributions}

Conceived and designed the experiments: $\mathrm{Z}$ Hussain, ZH Facho \& I Hussain, Performed the experiments: Z Hussain \& H Shafqat, Analyzed the data: N Rahim, A Khaliq \& A Shaheen, Contributed materials/ analysis/ tools: ZH Facho, Wrote the paper: MM Tahir \& Z Hussain. 


\section{Acknowledgements}

We are thankful to Department of Agriculture, Skardu for providing transport facilities for collecting soil samples and the staff of the laboratory of Soil Research, Skardu for Soil analysis.

\section{References}

1. Agriculture statistics of Pakistan (2017). Ministry of national food security and research. Government of Pakistan.

2. Khalid R, Mahmood T, Bibi R, Siddique MT, Alvi S \& Naz SY (2012). Distribution and indexation of plant available nutrients of rainfed calcareous soils of Pakistan. Soil Environ 31: 146-151.

3. Oechel WC, Vourlitis GL, Hastings SJ, Zulueta RC, Hinzman L \& Kane D (2000). Acclimation of ecosystem CO2 exchange in the Alaskan Arctic in response to decadal climate warming. Nature 406: 978-981.

4. Cambardella CA \& Karlen DL (1999). Spatial analysis of soil fertility parameters. Precis Agric 1: 5-14.

5. Cihacek LJ \& Swan JB (1994). Effects of erosion on chemical properties in north and central region of the United States. J Soil Water Conserv 49: 259265.

6. Jobbagy EG \& Jackson RB (2000). The vertical distribution of soil organic and its relation to climate and vegetation. Ecol Appl 10: 423-426.

7. Havlin HL, Beaton JD, Tisdale SL \& Nelson WL (2010). Soil Fertility and Fertilizers: An introduction to nutrient management. $7^{\text {th }}$ Ed. Pearson Prentice Hall; New Jersey (USA) pp 166.

8. Khadka D, Lamichhane S, Khan S \& Pant SJBB (2016). Assessment of soil fertility status of Agriculture Research Station, Belachapi, Dhanusha, Nepal. $J$ Maize Res Dev 2: 43-57.

9. Sharma VK, Dwivedi KS, Tripathi D \& Ahmed Z (2006). Status of available major and micronutrients in the soils of different blocks of Leh district of cold arid region of Ladakh in relation to soil characteristics. J Ind Soc Soil Sci 54: 248-250.

10. Rajput MM, Gandahai AW, Memon, M, Kaleri AA, Sootahar MK, Kaleri SH, Sootahar MK \& Panhwar AA (2017). Analysis of physio-chemical properties of guava orchard in multi zone of District Larkana, Sindh, Pakistan. Pure Appl Biol 6: 841-849.

11. Tandon HLS (1993). Methods of analysis of soil, plants, water and fertilizers. New Delhi, pp 144.

12. Walkley AJ \& Black IA (1934). Estimation of soil organic carbon by the chromic acid titration method. Soil Sci 37: 29-38.

13. Soltanpour PN \& Workman S (1979). Modification of the $\mathrm{NH}_{4} \mathrm{HCO}_{3}$-DTPA soil test to omit carbon black. Comm Soil Sci Plant Anal 10: 1411-1420.

14. Ryan J, Estefan G \& Rashid A (2001). Soil and Plant Analysis Laboratory Manual. 2nd Ed. International Centre for Agricultural Research in the Dry Areas Aleppo, Syria and the National Agricultural Research Centre, Islamabad, Pakistan, pp 172.

15. Deshmukh KK (2012). Studies on chemical characteristics and classification of soils from Sangamner area, Ahmadnagar District, Maharastra. Rasayan J Chem 5: 74-85.

16. Dahnke WC \& Whitney DA (1988). Measurement of soil Salinity. In Dahnke WC, editor. Recommended soil chemical test procedures for the North Central Region. NCR Publ. 221. Revised. North Dakota Agric. Exp. Sta. Bull. 499. Fargo, ND, pp 32-34

17. Khattak RA \& Hussain Z (2007). Evaluation of soil fertility status and nutrition of orchards. Soil Environ 26: 22-32.

18. Ashri A (1998). Sesame breeding. Ann Rev Plant Breed 16: 179-228.

19. Landon JR (1991). Booker tropical soil manual, Hand Book for soil survey and Agricultural land evaluation in Tropics and sub-tropics. Longman. New York. $74 \mathrm{p}$ 
20. Jabeen S, Shamsi IH, Adil MF \& Zhan Q (2017). Spatio-cliamtic variability in soil physical properties and bioavailability of potassium under different land use systems. Research \& Reviews. J Microbiol Biotech 6: 36-44.

21. Babar K, Khattak RA \& Hakeem A (2004).

Physio-chemical characteristics and fertility status of Gilgit soils. J Agri Res 42: 305-312.

22. Shaheen A, Shafiq M, Naeem MA \& Jilani G (2008). Soil characteristics and plant nutrient status in the eroded lands of Fatehjang in the Pothwar plateau of Pakistan. Soil Environ 27: 208-214.

23. Baize D (1993). Soil Science and analysis. A guide to current use, John Wiley and sons Ltd, West Sussex. 201 $\mathrm{p}$

24. Ishaq S, Begum F, Hussain K, Abbas Y, Ali K, Ahmed S, Amir R \& Karim R (2015). Soil quality assessment in gulmit and shiskat valley of upper hunza, district Hunza Nagar, GilgitBaltistan. J Biodiversity Environ Sci 7: 87-95.
25. Smaling EMA \& Broun AR (1996). Soil fertility research in Sub-Saharan Africa. New dimensions, new challenges. Comm Soil Sci Plant Anal 27: 365-386.

26. Lal R (1987). Response of maize and cassava to removal of surface soil from an Alfisol in Nigeria. J Tropical Agri 59: 77-92.

27. Sharma PK, Sood A, Setia RK, Tur NS, Mehra D \& Singh H (2008). Mapping of macronutrients in soils of Amritsar District (Punjab) A GIS approach. J Ind Soc Soil Sci 56: 34-41.

28. Memon M, Akhtar MS, Memon KS \& Stuben D (2011). Phosphorus forms in the Indus River alluvial and loess, shale and lime stone derived alluvial soils. Asian J Chem 23: 1952-1962.

29. Sadiq M (1986). Proc. Intl Forum Soil Taxonomy and Agro-technology Transfer. 113-118.

30. Whiteman (1985). Mountain Oases. A technical report of agriculture in Hunza, Ishkoman and Yasin valleys of Gilgit District. Northern Areas FAO.UNDP.PAK.80/009, pp 28-40. 